\title{
Editorial
}

\section{Riesgo en la manipulación y consumo del dióxido de cloro y clorito de sodio}

En la actualidad, en todos los países, se observa que algunas personas inducen el uso de todo tipo de sustancias y preparados con tal de prevenir o tratarse del COVID-19 y en su desesperación algunos consumen e incluso se inyectan sustancias químicas peligrosas, lo cual es sumamente preocupante.

Siendo el mercado informal de nuestro país algo normal, la venta de diversos productos químicos por las redes sociales se ha vuelto cotidiano. Aparte de las medicinas, muchas de ellas adulteradas -que sin recetas médicas se compran por la Internet- hay tres compuestos peligrosos que se venden sin control por personas no autorizadas y sin pericia en el manejo de sustancias peligrosas y además los manipulan temerariamente, ellos son: clorito de sodio, dióxido de cloro y ácido clorhídrico.

El dióxido de cloro es un gas amarillo rojizo que fue descubierto por Sir Humphrey Davy en 1814 y se comercializa desde los años 20 del siglo pasado como desinfectante. Se trata de un oxidante muy fuerte, muy reactivo e inestable que incluso puede explotar. Si bien es soluble en agua se descompone por fotólisis, generando especies como el radical hipoclorito, ácido cloroso y ácido clórico que luego se descomponen. Se conoce que reacciona violentamente con mercurio, fósforo, azufre, entre otras sustancias, lo cual es un peligro porque podría originar fuego y explosión. El dióxido de cloro es una sustancia corrosiva cuya inhalación causa tos, dolor de garganta, dificultad respiratoria, entre otros daños. En contacto con la piel causa desde enrojecimiento hasta quemaduras cutáneas graves.

Para preparar el dióxido de cloro el personal capacitado y autorizado lo obtiene al reaccionar clorito de sodio con ácido clorhídrico para su uso como desinfectante. El clorito fue observado primero por N.A.E. Millon en 1843, pero fue investigado mucho más por G. Bruni y G.R Levi en la primera y segunda década del siglo pasado. Este compuesto tiene riesgo de incendio y explosión. Su inhalación causa dolor de garganta y tos y en contacto con la piel causa enrojecimiento y dolor. Al ser una sustancia fuertemente oxidante reacciona violentamente con muchos reductores, en especial combustibles.

Como uno de los usos del dióxido de cloro es en el tratamiento de agua, la EPA(Environmental Protection Agency) ha establecido niveles máximos de presencia de clorito en agua potable de $1 \mathrm{mg} / \mathrm{L}$ y para el dióxido de cloro de $0,8 \mathrm{mg} / \mathrm{L}$. Asimismo, los trabajadores que usan este compuesto como desinfectante saben que el límite de exposición ocupacional al dióxido de cloro para una jornada de 8 horas diarias, 40 horas por semana, es de 0,1 partes por millón (0,3 miligramos por metro cúbico $\left.\left[\mathrm{mg} / \mathrm{m}^{3}\right]\right)$.

Toda sustancia de uso médico debe pasar por un control de calidad. Un mercado informal de insumos no garantiza la calidad de los mismos en cuanto a su pureza o presencia de

contaminantes. Como el clorito de sodio lo venden como desinfectante, se desconoce su 
pureza y nadie sabe cuáles son sus contaminantes. Asimismo, siendo el ácido clorhídrico una sustancia sujeta a registro, control y fiscalización algunas personas, de manera ilegal, en el Perú la venden desconociéndose además su calidad.

Los usos supuestamente médicos del dióxido de cloro y su venta se iniciaron en Estados Unidos en el 2006, donde sin ningún sustento clínico algunos de los vendedores indicaban que curaba la malaria, luego incorporaron el autismo, ébola, gripe H1N1, cáncer, etcétera. Tras un tiempo, su venta se trasladó a Europa y a otros continentes. Ahora, en tiempo de pandemia, sus promotores dicen, sin prueba alguna, que cura el COVID-19.

Una revisión crítica en las publicaciones relacionadas con el dióxido de cloro indica que muchos son estudios químicos, biológicos y toxicológicos; la mayoría son estudios preclínicos. Como se sabe, para que una sustancia sea aprobada con fines medicinales se debe cumplir con los estudios clínicos de las fases I, II y III, tras lo cual se derivan a instituciones como la FDA, que tras exhaustiva revisión la aprueban o desaprueban. A la fecha no existe ningún documento que acredite que haya pasado estas fases el dióxido de cloro. En vista de ello, y de los peligros de intoxicación que ocasiona este compuesto, ningún organismo de salud ha aprobado el uso del dióxido de cloro con fines médicos; es más, vetan su uso y alertan a la población de los problemas de salud causados por este compuesto.

Cuando la histeria social induce a las personas a consumir sustancias muy peligrosas para la salud es bueno recordar que en el año 1667 se publicó el libro History of the Royal Society encargado a Thomas Sprat y supervisado por R. Boyle y J. Wilkins, que en un párrafo señala "la actividad científica consiste en recoger los hechos de la naturaleza, absteniéndose de recoger teorías generales que se "anticipen" a ellos, huyendo de los sistemas dogmáticos generales, de la retórica, las sutilezas dialécticas y la fantasía, buscando a cambio la aplicación útil”. Sabias palabras que siglos después recobran importancia en tiempos de coronavirus.

Dr. Mario Ceroni Galloso Miembro de la SQP 